\title{
ГЛОБАЛИЗАЦИЯ И КРИЗИС В ЗАКОНЕ: ПЕРЕОСМЫСЛЕНИЕ ЭТИКИ И МОРАЛИ В СОСТОЯНИЕ ПОСТМОДЕРНИЗМА
}

DENDASCK, Карла ${ }^{1}$

Сильва, Осиас Адония ${ }^{2}$

DENDASCK, Карла; Сильва, Адония Осиас глобализация и кризис в законе: переосмысление этики и морали в состояние постмодернистской междисциплинарный научные знания ключевых журнал-Vol. 1. Год. 1. Марта. 2016, pp: 98-119-ISSN: 0959-2448

\section{PEЗЮME}

Этот тест направлен критический анализ на технологической и экономической глобализации и ее воздействии на позитивном праве, с его официальное лицо normativista логики контексты, которые являются более сложными и изменчива. Исходя из этой предпосылки, он предназначен для оценки, как этика и мораль может служить с севера в этой парадигмы, которая необходима для применения закона, который лучше всего соответствует чаяниям граждан в обществе, в постоянном изменении. Цель заключается в том, чтобы проанализировать роль прямо под этой новой предвзятости глобализации и ее актуальность для современного человека.

Ключевые слова: этика. Моральный дух. Глобализации. Право

1 Доктора в психоанализе, после защиты докторской сотрудник клинического психоанализа, магистра биоэтики-директор центра исследований и передовых исследований email: prof.dra.csd@hotmail.com.

2 Юрист, аспирантуры в области налогового права; Степень магистра права в Paulista Escola de Direito; adonias.Silva@unifesp.br. 


\section{ВВЕДЕНИЕ}

Генеральной sabença, что траектория человек на планете, начиная в пещерах до homo sapiens, когда человек начал осознавать свой интеллект и установить вверх его свободу для преодоления препятствий, которые всегда пересек его путь, всегда был отмечен участие в строительстве права и справедливости.

Даже на заре цивилизации, когда не идею совершенствования права и справедливости, как мы сегодня, человек всегда боролся что актер его собственной истории и в пределах этой мелодии стал политическим и моральным, который действовал в рамках своей концепции этики и морали.

В самом деле, можно отличить человека от других живых существ именно для его интеллектуального развития, которое в свою очередь непосредственно связано с его поведения в обществе, то есть, в своих моральных процедуры проявляется через их отношения на коллективное сосуществование со своими сверстниками, который является не происходит с другим живые существа, которые действуют лишь инстинктом. Что его место среди других машин, самоходные природы является то, что дает видное место как социальные Dominator (Реале, 1994).

С социальные обычаи передавались от отца к сыну отношения социальных групп эволюционировали от простых парадигмы сосуществования до тех пор, пока командной структуры, более твердой, как Закон о positivado и что вследствие высшей стадной человеческого существа от их социального сосуществования сделал exsurgir право, как социальное явление их собственной культуры с своих правил и санкций.

И ратифицировать эту реальность, есть латинского принцип, который говорит: "ubi societas, ibi ius est» (где есть общества, будет существовать право). Это отправная точка этого теста, так как общество развивается, она стала глобальной, и позитивном праве с ее фрормальных правил, кажется, больше не 
может удовлетворить чаяния Этот современный человек, что в глобализованном мире следует за в его вечное путешествие достижения справедливости.

Глобализация, которая пришла рука об руку с технологической революции и экономические изменения, после того, как выиграл свой первый этап установки, которая заключается в интеграции мировых рынков, теперь представляет нам с новой проблемой являются последствия и воздействие на правовые институты. Большой проблемой является знать который эффеективности и охвата правовых институтов и правовых инструментов для этой новой реальности глобализации человек.

Кроме того нельзя забывать о роли этики и морали современного права, основы для справедливого общества и правильно. Простой фракт, что, на практике, практическое применение закона делается через распределенные правосудия для человека - судья - правовой системы лежит с мистером достопочтенный решить спор между сторонами в споре в поисках приговор можно увидеть такой факт.

В сравнении процедурный процесс в поисках предложение, что вы понимаете, что они находятся в конфронтации не только правовой, но все этические и моральные принципы, процессуального права требует не только тяжущихся, а также его собственные судьи. Камнем преткновения является как быть этические в вырожденных коррупции, привел в рамках глобализации и их технологических систем, где вы можно присваивать от простой выбор ликвидатора кондо до проведения выборов для выбора наших правителей.

Экономическая глобализация налагает на обязанность человека быть Рико, чтобы иметь, чтобы обладать любой ценой и технологические инновации являются треки, которые приведут тепловоза обмана, под прикрытием идти, что цель оправдывает средства, дальше и люди этических и моральных ценностей, полученных от колыбели. И в этой системе nexted «Герсона и закон», легкость любой ценой, является закон, со всеми ее аспектами и детерминанты. 
Это о кризисе в право обращаться в этом тексте, принимая во внимание аспекты глобализации, который сделал мир в глобальную деревню и взял с собой ценности этики и морали препроводил нам нашими отцами-основателями. Мы живем сегодня в более сложных условиях и изменяемым, что шумно для контекстуального права, который отвечает текущим потребностям человека, которые уже не тот же человек, вставляется в контексте прошлого века.

Что можно сказать из бетона, что государства и права, по образцу традиционных мы развертываются в обществе сегодня, не подходит для социальных изменений, испытываемых людьми в обществе. Сегодня, более чем когда-либо право необходимо принимать другие направления, если вы хотите, чтобы удовлетворить чаяния этого человека. Имеет право обратиться к альтернативным средством, то есть, закон должен быть право ведения переговоров, круглых столов, арбитража и посредничества.

Очевидно то, что пути, которые привели нас это далеко не будет то же самое, что будет принимать нас теперь. И по этой реальности является допустимым для анализа в какой степени право positivado, с фрормальной логики и негибкой, можно встретить удовлетворение чаяний этого глобализированного человека, в частности в связи с этической и моральной аспект. Это не необходимость сохранения этики и морали, не теряя из виду закона и его правильного применения в конкретном случае.

\section{ГЛОБАЛИЗАЦИЯ В СОВРЕМЕННОМ ГОСУДАРСТВЕ}

История показала, что человек всегда боролся для улучшения условий их жизни. Человека конгломератов уже приняла форму городов около 3500 до н.э. и его социальном контексте возникли воины с их примитивные оружия были подделаны для защиты социальной группы. От этого возникает конструкторов его мансардная крыша, которые доминировали использования воды, и тех, кто с его мудрость научились интерпретировать явления природы и стал их священники и судей. 
От этого начального развития человека и общества, эволюционировали несколькими способами и в несколько этапов что вы не хотите, чтобы здесь анализирует их, поскольку этот документ не поддается этот срыв. Однако стоит отметить здесь только abolutismos, что отмечены первые дни современного государства, которая принесла как характеристика монополии на применение насилия со стороны тиранов, что абсолютным способом проведено власть любой ценой, будучи не только законодатели, но также судить их собственных.

Государства, с тем чтобы сохранить социальный мир под угрозой или нарушены, запретил autotutela и призвали ответственности для разрешения споров. С этого момента государство теперь имеет функцию применения закона в конкретных случаях и исправить конфоликт.

В результате государства как владельца порядка, закона и справедливости путем ограничения области правителей в строгих рамках закона, давая судебной исключительной компетенцией судить и урегулирования конфликтов и это делает его через юрисдикции. Юрисдикции слово приходит из состава двух слов: jus латинских существительных, Юрис, означает «прямо», более третьего спряжение глагола dicere, означает «сказать», «говорить», «Экспресс». Таким образом юрисдикция является власть, государство имеет право сказать.

Однако юрисдикция является инертным, согласно латинского принцип: «nето безотлагательно t и синус; CB procedat безотлагательно t officio (судья не без актер; судья ex officio). Поэтому искусство. 2 гражданского процессуального кодекса, который таким образом prolata: «судья не обеспечит судебную защиту, в противном случае часть или заинтересованных применить, в случаях и законных способов».

По этой причине так что государство может предложить производительность и осуществлять свою роль как посредник споров нет необходимости, что держатель конфликтующих интересов в правовых отношениях закон материала имеет инициатива и перейдите стучаться в двери судебной системы. По необходимости, действительно отметить, что хотя государство не обладает 
юрисдикцией для начала, раз вызвало юрисдикционные функции государства, процесс будет разработан официальный импульса до ее завершения с предложения, положить конец сделки.

С ростом населения и экономического, технологического и социального роста спрос граждан, нажав на двери судебной власти пропорционально больше, чем ответов, для тех, кто ищет ответ на их требования и споры. И в результате этого в том, что судебной системы, которая больше не отвечает требованиям там приняты, судебной активности, которая не соответствует интересам граждан.

Сегодня с глобализацией, проблемы, с которыми сталкивается общество, полностью отличаются от тех, кто пережил поколения назад и тенденция является увеличение этих трудностей, и уверенность, что у нас есть, что судебная система не готова для изменений, которые представляют себя следующего поколения, которые мы обсудим в следующих строках.

Когда речь заходит о то, что глобализация имеет в виду серьезный анализ процессов и взаимосвязанных и изменения, которые происходят на мировой арене и с ним весь путь мышления, действуя и жизни в обществе существенно меняется. Эти изменения затрагивают не только экономических и социальных структур, которые препятствуют непосредственно в текущем легального производства и в результате, в форме мышления и сделать правильный.

Первое, что вам нельзя не упомянуть является вопрос о суверенитете государства перед лицом роста multinacionalismo и транснационализма. С ростом многонациональных корпораций и появление наднациональных транснациональных агентов и безудержной принесла глобализация государство видит свою силу, смягчены в отношении регулирования и структурирование экономического регулирования, а также в отношении защиты отдельных лиц и общества. Некогда исключительной компетенции государства-нации, от глобализации будет цель и интерес других транснациональных и многонациональных учреждений. 
Многонациональных компаний, с их возможностями для расширения, как производства, так и других операций по всему миру, несмотря на его важность для социального и экономического развития, навязывать право совершенно другой образ мышления, принесли формы в прошлом веке, и что были увековечены в истории. Легкость, с которой эти компании должны переместить свои заводы из одной страны в другую, а также их потенциальные мировой торговли, требующие права обзор и более открытой и менее систематический, закрытые и расположен как текущий.

Актуальность этих компаний для глобальной экономики приводит к изменению фрокуса на социальные отношения, со всей его сложности, требует адвоката не только национальной точки зрения, однако, взгляд «за пределами», т.е. Глобальный взгляд. Даже что стало общим местом, если вы услышите, что «мир является глобальной деревне» означает, что заборы, стены и границы, которые нас отдельно от наших соседей, теперь уже не может быть мельком.

Такая реальность затрагивает право на всех уровнях и имеет свои разработки в этические ценности, моральные и хорошее поведение, что требуется от гражданина, вступила в этом глобализованном социальном контексте. Подвергаются все риски, вызванные глобализацией, этот гражданин, судебной спроса ответ на ваши потребности, вы не найдете право более чем концепций и официально созданы институты и определяется, кто не может удовлетворить ваши потребности в рамках этой глобальной сложности.

По этой причине мы можем сказать, что глобализация указывает на изменения в гражданских, уголовных, административных, деловых и, прежде всего, международного права, необходимо постоянно адаптировать для удовлетворения новых и необычных ситуаций, которые до тех пор, пока некоторое время назад считались существовать, например, глобальной торговли и фринансовых рынков союз, что, несмотря на его гибкость для создания единой столицей глобально и облегчению свободного потока инвестиций без границ , Новая реальность и рассеянной в действующий закон. 
Еще одним фактором, который необходимо рассматривать в этом глобализованном мире проблема роста региональных экономических блоков, как это непосредственно влияет на modus operandi права как в нашем обществе. Что является более распространенным сегодня и что каждый год увеличивается, является обмен между региональных торговых блоков, а именно сокращение торговых барьеров между странами. Только не забудьте Акронимы как ЗСТСЮА, MEРКОСУР, UEA, просто назвать несколько из этих блоков, которые вместе с коммерческим сродства. Не вызывает сомнений то, что сегодня Международная торговля является реальностью и неолиберальной концепции, которые были более гегемона, открывают двери многих стран, ранее закрытых для диалога, как это происходит в странах Восточной Европы, бывшего Советского Союза и с позитивным размышления на Китай.

Свободную международную торговлю и акцент усиливают частные рынки как-то decentralizes и уменьшает роль правительства, который всегда был регулятор экономики. Это изменение к свободной торговле такие аттракционы, которые повлияли непосредственно экономической политики «Дядя Сэм», а также Европейской экономической политики в целом, ведущих к созданию организаций как МВФ, МБРР (а также региональные банки и ГАТТ) и распространяет его последствия в глобализованном мире.

И если все эти изменения не были достаточно нарисовать график нынешнего общества, вы все еще можете говорить на глобальная тенденция к демократизации, защиты прав человека, гораздо больший интерес в области права, учитывая юрисдикционные функции государства, первоначально указал. Параллельно с вопиющие проявления экономических изменений, огромные усилия на международном уровне, создание либеральной политики, которые направлены на защиту индивидуальных прав человека, а также элементе арбитража и укрепление правовых институтов какой приходят действительно судебный запрос для предоставления гражданам, vis-à-vis диффузных и коллективные интересы. 
Параллельно все это вы также найдете НПО, которые являются транснациональными и наднациональных актеры, которые появляются в этой ситуации в целях защиты прав человека, прав обездоленных слоев населения, право на устойчивой окружающей среды, прав коренных народов, прав этнических меньшинств, вопрос о аффрективных в обществе, гомо, только чтобы назвать некоторые из них. Вы не можете забыть, что все эти вопросы являются частью повседневной жизни гражданина и общества надеется на удовлетворительный ответ и вы приходите, чтобы узнать, что современный человек, который, кажется, было предложено покинуть пещеру, однако не были предоставлены средства для перемещения, поэтому по-прежнему погружен в все, что вы видите вокруг вас чувствую себя беспомощным и не готовы противостоять этой новой реальности.

Анализировать все, что эта глобальная проблема является патентный закон стремится сантехника и вождения конфликты и столкновения возникли в обществе, поэтому следует говорить не только в радикальной и срочные, в всего фитнес концепций традиционно используется, в таким образом, в так же, как человек пришел из пещеры также право делать так же, как и прийти, чтобы узнать, что современный человек в разгар хаотическое общество, глобализованного мира и опыт многочисленных конфликтов на всех уровнях.

\section{ПОЗИТИВИСТСКАЯ ЗАКОН И ФОРМАЛЬНОЙ ЛОГИКИ}

Это не позволяет говорить в позитивизм в правовом поле без буксир для Рис Hans Kelsen. В самом деле хотя он считается отцом позитивизм стоит подчеркнув, что все ab initio позитивистской доктрина была построена с годами и имел его ведущую роль в развитии права как науки.

Для Kelsen закон следует понимать как норма, оторванный от любой социальной или оценочные дизайн. Просто думаю этого режима является то, что основой его работы, известный как чистая теория права, выпуск этой юридической науки ко всему содержимому, на оптике Kelsen, не свой собственный. Предлагая что Сплит, немецкий юрист стремится дать правовую автономию науки своей 
собственной, полностью свободного от элементов, которые не принадлежат к ним.

Для Kelsen чисто юридическая наука должна быть безошибочно психология, социология, политика и мораль. Хотя таких наук связаны в некотором роде вправо и крест ваш путь большую часть времени, пока юридической науки не пропитанные такие концепции за пределами своей области знаний. Такое понимание, хотя это звучит странно для ушей, имеет значение, когда вы хотите говорить о справедливости, как будто с помощью точного языка и жестко логические, Kelsen реферировать правильной концепции идею справедливости.

Правосудие является всегда и неизменно тесно связаны с ценностями (всегда переменных) принят тот, кто вызывает (будь то, социологического, психологического или моральные аргументы), не будучи концепция права общепризнанных, из-за неточности и текучесть означает, делать то, что для данного контекста или общества, что бы не справедливо к другому.

В видении адвоката право ограничивается набор правил представлены категории требований «должно быть» и таким образом приносит фракты правового масштаба или antijurídico. С этим один четко понимает, что Kelsen создает этики на основе различия между быть и должно быть. Другими словами, Kelsen проводится различие между как вещи, как вещи должны быть и эта связь между «быть» и «должно-быть "заканчивается в два различных аспекта, и которые имеют решающее значение в его дизайн. Первый из этих аспектов относится тот фракт, что это различие между бытием и должно-быть служит для различения между двумя способами, в которых можно изучить закон: Первый это видение закона, как это, и второй, по мнению закона, как это должно быть. Второй аспект, что это различие также служит, чтобы сделать поворотным раскол между царство фракты, относящиеся к быть- и Королевство стандартов-должны быть связаны. Таким образом, следующее уравнение: невыполнение обязательств (отсутствие фракт), предполагает санкции (должно быть). Яснее словами: отказ (обязанность), должен быть штраф (санкции, установленные в стандарте). 
В этом контексте Kelsen отмечает, что стандарт является продуктом воли, составлен с целью регулирования поведения человека и который служит толкование. Здесь необходимо подчеркнуть, что для позитивизм стандарт имеет не действительность для ощущение ярмарка, но простой факт подключения к другой стандарт рассмотрен Улучшенный он назвал основные стандарта. Именно из этой методологической концепции основных стандарта, который юрист может создать систематизации всей правовой системы.

Один из его более далеко идущие практических теоретических концепций является идея правовой системы как многоуровневого набора структурированных правовых норм в фрорме пирамиды, абстрактные, прерывистого и доминируют Конституции штата, которая делает другие правовые нормы нижней иерархии (различные подконституционного законодательства и других нормативных актов). Эта теоретическая концепция, что экстракты концепции конституционного жесткость, которая является включение и системы для защиты целостности Конституции требуется. Хотя существуют споры о создании нормативно пирамиды, для целей этого эссе приписывается Kelsen.

Еще одним важным вкладом юриста в практический мир закона было в Конституции Австрии с 1920 года, составленный под его вдохновения. В тени влияния Kelseniano, думал это письмо австрийской политики, маркетинга для предыдущих нововведенных позитивного права, понятие концентрированной контроля конституционности законов и нормативных действует как судебные функции Конституционным судом, взимается с исключительной фрункцией целостности Конституции.

От там конституционной юрисдикции может быть разделен на две части: конституционной юрисдикции (концентрированный контроль конституционности) и диффрузный конституционной юрисдикции (диффрузный контроль конституционности). Этот последний режим охраны (диффузный) Конституции была уже практикуется в Соединенных Штатах Америки. 
В бразильской правовой системе, под эгидой федеральной Конституции 1988 года, Конституционная юрисдикция практикуется оба способа: концентрат, действиями компетенции Верховного суда и диффузный, ли выполнен в отчетах о каких-либо действий (и ресурсов эти присущие) в пределах юрисдикции любого суда, судей или судов.

Таким образом при обсуждении Kelsen мы не можем упускать из виду основной вопрос его мышления, которая является обоснованность верховенства права и их иерархии, что это один из наиболее важных аспектов его теории.

Прежде чем выше можно увидеть что позитивистской закон представляет собой набор правил, регулирующих поведение человека и эти стандарты, в свою очередь, когда допустимым и законно предполагаемой недостаточности приобретают право устанавливать санкции, ввиду своей структуры, характеризуется как принудительные порядок и что применяется, только если вы неразрывно связаны с другой стандарт.

Большой проблемой, которая представляет собой относительно правовой позитивизм является то, что, несмотря на то, что он представляет собой систему правил, регулирующих поведение человека в обществе, но негибкость правой positivado не может удовлетворить интересы того же человека. Этот третбан стоит отметить критику сделанные Дворкин правовой позитивизм, сказав, что позитивизм настолько догматических, что «закон часто становится то, что говорит судья» (Дворкин, 2003, стр. 4). Эта критика Рональд Dworkin делает контрапункт к закону позитивистской, показаны теоретическую модель, которая является областью дать адекватный ответ на вопрос о толковании, который он называет целостности права

Ну, это нетерпимо догматизма юридического позитивизма, который в конечном итоге уменьшить права заявление некоторых судей является то, что, принимая надежды граждан, низводя право только на мир идей, что должно быть, а не реальный мир, что ожидается, когда он вошел судебной власти с требованием: конкретность иск. Не говорить о здесь, в справедливости, потому как уже 
упоминалось, правовой Позитивизм не имеет эту претензию к правосудию, но просто стремится обеспечить общепризнанных концепция права, помимо других социальных реалий. Смысл здесь заключается в том, что по крайней мере так жаждал юрисдикционные положения вступили в силу в действительности и в законодательстве и не только theorized в правовых положениях, вербализации, Тога.

\section{ЭТИКА И МОРАЛЬ В ПРАВОМ}

Когда дело доходит до этики и морали в правом, нельзя не упомянуть, что поведение человека по отношению к другой, в каждом социальном контексте в судебные поединки, проведенных к правосудию, всегда имеет сильную моральную наклонной.

Единственное различие между этические и моральные постулаты и право является последний имеет свой коэрцитивной силы регулируется правовой системы, что определены все накладывается с ее правилами и стандартами, который диктует приносят с собой наказания ответственность которых они представляют.

Позитивистская юрист Hans Kelsen (2001:36), уже упоминалось в этом тексте, приносит важный вклад в понимание этой темы этики и морали в правом. В его работе, «что такое справедливость» немецкий ученый так выражается:

Признавая право как конкретные принудительные методики социального порядка, мы можем сравнить его с других социальных заказов, в части, они преследуют те же цели, закон, но разными способами. Закон является конкретной социальной среде, не конец. Закона, морали и религии - все три запрещают убийство. Но закон не так, предусматривая, что: Если мужчина совершает убийство, другой человек, определенным законом, применяется против убийцы, некоторой степени принуждения, предусмотренные правовой порядок. Просто требуют Мораль: не убий. 
Примечательно, что хотя мораль не мощь и силу установить санкции за неповиновение, равно как и право, до сих пор его нельзя игнорировать учеными права, начиная с даже до правой positivado c их моральных стандартов и концепций уже был использован в примитивных обществах как средство для руководства и привести отношения в социальной праздничности.

Таким образом различие между моральной и правовой принцип-это тонкая грань и они часто идут вместе и далее и которые разделяются только ее последствия. Позвольте нам взять в качестве примера сына что когда мимо его отец и получает комплимент не взаимностью же вежливости, или даже отвлекает, такое поведение является моральное преступление, для которого существует правовой боли. Однако, если этот же сына, чтобы быть встречено его отец приводит к травме, в этом случае совершает преступление предусмотрено в планировании и должны быть наказаны.

По этой причине, Chaïm Perelman (1996:289), великий фрилософр Брюсселя и один из величайших философов XX века. XX, заняться этой темой и моральный закон, покинул зарегистрированы следующие:

Традиционно, настаивать исследования, посвященные отношениям между правом и моралью, в духе кантианский, в какой уважаемого: право регулирует поведение; Мораль подчеркивает намерение, Закон устанавливает связь между правами и обязанностями, моральной обязанности предписано, что не давать субъективных прав, Закон устанавливает обязательства, санкционированных властью; моральных санкций организованный отдых. Адвокаты, недовольны позитивистской концепции, статистики и формалист, настаивать на важности моральный элемент в силу закона, в роли, что они играют, добросовестность, недобросовестности, злого умысла, морали и многие другие понятия, чьи этический аспект не презирал.

Словами философра ученого из Брюсселя уже можно получить представление о той степени, что морали и этики играть в применении закона по сей день. Мы живем в обществе, где этические и моральные ценности следует путать с личных 
и частных интересов, и именно поэтому эти значения чаще отодвигаются на задний план, клейма потребительского общества, где какие вопросы является достижение целей, независимо от средств, используемых для сделать это, делая старый принцип преобладает, что цель оправдывает средства.

Потому что это именно в что тонкая грань между моральных и этических ценностей и морали, что право должны идти свой путь, как только компания приходит потерять эти значения для каждого поколения. Во время наших отцов простое слово печатью юридического и бизнес была проведена до обстоятельства.

В настоящее время, даже когда окружении все гарантии, ценных бумаг и все, но у вас есть реальные гарантии того, что юридический бизнес будет прийти к термин способом, без вмешательства государства, осуществляющего свою роль coator требуют правила изначально compactuadas.

На это социальные требования, введенные в настоящее время право способ материализуется в процессе, через решение судьи, приносит вверх всю коллекцию человеческой культуры в интересах тяжущихся перед лицом государственного суда, который все чаще принимает его роль делегат coator обществом.

Не вызывает сомнений то, что в сравнении практику процедуры были приведены в конфронтацию не только правовые нормы, но также все этические принципы, которые закон процесса требует тяжущихся сторон и даже сам судья. Бокам свободы есть вся структура преданности и искренности, что требуется по закону в заботах и судебной связей. То, что вы должны получить это не просто positivada стандарт и формальных, но также этических и моральных ценностей в качестве важных элементов претензии стремились судебного пересмотра.

То, что общество организуется сегодня, с всеми инструментами социального контроля и увеличение информации через технологии и экономического роста по причине глобализации, больше не поддается лишь свидетель юстиции. 
Напротив, отсутствие правовой основы показал, что наблюдается сегодня, более чем когда-либо, это общество пытается взять закон в свои собственные руки, пытаясь заполнить вакуум, образовавшийся судьями судебной подотчетности, но к сожалению работает неправильно, делая, часто под прикрытием правосудия, несправедливости еще больше. Все это для этой правовой формализм, который ищет только в технике и совершенствование законов, что ответы на социальные проблемы, которые делает его ясно, что эта модель больше не поддерживается в современном обществе.

Как это действует здесь отметить слова итальянский юрист Франческо Карнелутти (2004:60), который имеет: «Если закон является инструментом правосудия, не технику или наука достаточно для обработки он.» Это подтверждается словами итальянского юриста ínclito, проведенное практического применения закона, который вы делаете юстиции в юридических конфрликтов, требует большего, чем юридические методы и стандарты управления юстиции. Большой вопрос, который вы не можете скрыть является ли прямое применение как это делается в эти дни, positivado, готовы и формальной, действительно визы правосудия. Один можно увидеть что применение практических проблем, привлечены к судебной власти не ответ до установленных правовых концепций и строго фрормальных.

Он был не без оснований, что Jhering (2012:322) говорит, что практические проблемы не хорошо адаптироваться к рай концепции в том, что многие адвокаты предпочитают жить. По словам Јоа̃о Маурисио Адеодато (2012:317), предложил менее догматической интерпретации Jhering, автор, который является международно считается одним из наиболее важных для догматики частного права.

Учитывая, что один понимает, что закон должен ходить в поисках баланса между normativista видение позитивизма о Hans Kelsen, где решение судьи должны определяться Пошта (следовательно позитивного права) и более экстремальные позиции 
предложенный актуальные Viehweg, для которого решение не должны держать связь с нормативными текстами. В этой связи Јоа̃о Маурисио Адеодато (2012:313) пишет с большим количеством имущества по теме:

Актуальные Viehweg, как представляется, привести к «открыть» чрезмерными по отношению к нормативного текста, который считается только выражение вершины среди других. В отказе постулат необходимой связи с догматической текстом, актуальные делает «ориентация по» метод слишком свободной и близится полномочиями на принятие решений.

Что делать, если попытки спасти является этот догматизма позитивного права, поиск только и только стандартный набор государством их поддержки базы, в ущерб моральные и этические аргументы в поисках справедливости. Что такое большее значение текущей правовой системы, estatalmente positivado и регулируется их собственные чрезвычайно формальных правил.

Как следствие этого формального и жесткой декорации, который больше не отвечает пожеланиям современного человека является, что альтернативные средства урегулирование споров, как посредничество, арбитраж, согласительной процедуре, который изобразить себя в качестве добавки к судебной власти в попытке сделать это. Такие институты привести в вашей среде, не только является альтернативой традиционным способом урегулирования конфликтов, но поиск и спасение, моральные и этические ценности, которые проявляются в действий арбитров и посредников.

В рамках сценария этих новых институтов, которые возникают в нашем обществе является что должна сиять, как профессиональный юрист поведения, тестирование его этике и моральную позицию перед лицом потрясений, которые появляются все более спорный аргумент. С другой стороны имеет право клиента, который спонсирует; с другой стороны, как противник, ответ другой стороной, которая также имеет его покровитель юрист. 
Именно в этом контексте адвокат должен осуществлять их трудной задачей в ваш клиент обороны интеллектуальной, однако, остался стоять и в соответствии с его веру в право на защиту и справедливость ищу, без забывать этических и моральных ценностей, которые привели его фрормирования до настоящего момента, т.е. все ваши этические и моральные наследия, сфрормированная в процессе его земной карьеры.

\section{ЭТИКА И МОРАЛЬ В ОСУЩЕСТВЛЕНИЕ ПРАВОСУДИЯ}

После анализа взаимосвязи между этики и морали, закон является действительный адрес другой стороне медали, которая является этика и мораль в осуществлении правосудия. Если positivado права, как это сегодня, поиск только стандартные контролируемые государством и жестко формального, без учета этических и моральных ценностей и морали, установленных обществом, это стоит сделать серьезного размышления о вкладе этики и морали в осуществление правосудия.

Известно, что объект моральной этики. Морали слово происходит от латинского, смысл «таможня», который, в свою очередь, является частью науки, которая заботится о хорошо, морали необходимо в социальной жизни человека. - Это набор правил для человеческого поведения как добродетель. Таким образом мораль является незаменимой для содержания этого права, особенно когда дело доходит до реализации юрисдикционные положения, которое происходит с помощью правосудия.

Наука о обязанности известен как этика и axiológicos принципы, которые регулируют их, не может обойтись без этики. По мнению выдающегося юриста Miguel Reale: «этика-это наука о нормативных стандартов.» Только человеку проводит это наследие, которое отличается от других живых существ, как уже упоминалось в начале этого текста.

Здесь действует слова José Renato Налини (1997:30), который известен как один из наиболее важных теоретиков изучения этики в Бразилии, которая выражена: 
Этика - наука о нравственного поведения мужчин в обществе. Это наука, потому что он имеет объект себя, свои собственные законы и собственный метод. Объект моральной этики. Мораль - один из аспектов поведения человека. Выражение происходит от Roman слово нравы с чувством манеры, набор стандартов, приобретенная привычка подтвердил его практики.

Таким образом можно предположить, что этика - это наука, изучающая акты человеческого поведения в социальном контексте, на основе лояльности и порядочность, в гладкости актов и достоинства осанки, так, что поиск истины больше цели должны быть достигнуты, выше личных и корыстных интересов, страстей. К сожалению, то, что наблюдается, что личные интересы преодолели моральные и этические ценности и реальное желание правосудия, и именно эта ситуация, которая может больше не поддерживаться в этом глобализованном и информационного общества.

Нельзя забывать о том, что является этика становится в этом текущем контексте, предварительным условием для того, чтобы жить праведной жизнью в этом глобализованном обществе. Без этики является невыносимой жизни в обществе и лояльности, которая является ее главной добродетелью, следует не только руководствоваться отношения, но, чтобы стать ядро самой своей сути.

Это не без оснований, что изучение этики приходит свыше веков и тысячелетий, и это является причиной для беспокойства для древней Греции и классической эрудиции, чьи взносы следует рассматривать до сегодня когда дело доходит до этика и моральные темы.

Вы можете просто в качестве примера, имя Aristóteles ${ }^{9}$, который признался в молодом возрасте как ученик Платона (который в 41 лет был назначен Филиппа Македонского для воспитатель Александра Македонского) и неисчерпаемый источник человеческой мудрости, посвященный его сына Никомах, родился его второго брака Herpile Стагира, одна из его работ по этике что еще сегодня публикуется в любой части мира. 
Согласно Barone Робисон (2012:23), в его адвокатом профессиональной этики грунт, цитирует estagirista следующим образом: "... это не теоретические исследования, как другие, потому что мы изучали не для того, чтобы знать, что такое добродетель, но чтобы быть хорошо, что в противном случае не будет вам никакой пользы» (Книга II Никомахова этика).

Tем не менее Miguel Reale (1994:24), еще один важный юрист национальной сцены, учит, что Аристотель, в восьмой книге Никомахова этика, развивает свою теорию справедливости, и он говорит:

... прилагательное несправедливости применяется два вида людей: 1) для тех, кто не подчиняться закону; 2) для тех, кто хочет получить больше, чем их доля т.е. та часть, которая по закону они должны предоставляться. Напротив ярмарка является то, что подчиняется закону и каково содержание с его стороны.

Не мог но помните знаменитый Барух Спиноза (2010), или Bendictus Спинозы, как он сам используется для входа в своих трудах, который также возиться с этой теме этики, разработки герметичные стиль, поскольку определение Бога, через пути в поисках свободы души власть разума.

Существует, таким образом, по словам этих благородных мыслителей, что этика имеет свою ведущую роль в осуществлении закона и в поисках справедливости. В теории, в отрыве от практики препятствуют и ударил курс судебной власти с годами. Стоит вновь заявляя, что говорил о сложности проблем, которые возникают в этом глобализованном обществе.

Очевидно, что мировой истории, написанные на головокружительной скорости и ускорения, в отличие от прошлых поколений, где успехи были медленные шаги и имел правильные условия в определенной степени, чтобы поддерживать себя и адекватно реагировать на проблемы граждан.

Сегодня, с развитием науки, новых открытий в генетических поле, чудеса и страшно рост Интернет, жизнь, созданный в лабораториях, клонирование человеческих существ, продолжительности жизни, поток новостей, увлечение с 
компьютера и с эпидемией мобильных телефонов, современный человек больше не имеет же уверенность что их предки. Теперь все это относительно: transmuda сегодня на вчера в скорость атома.

В что все разработки и передовые технологии, единственное, что человек не удалось, до сих пор была магическая формула солидарности, уважения другого человека, не худший и наиболее жестоких характер predator. К сожалению для разочарования это человечество, который очаровывает с передовые технологии и великих открытий и развитие науки, террор стал этические позиции другого, который действует яростно, как бессмысленные животное, не только иностранные, но также права узурпировать если бушуют против любого, кто хочет защитить такие интересы.

В этом контексте предполагается, что морали и этики являются ключевыми субъектами для спасения этого общества, поврежденных и жаждет закон и справедливость. Сегодня, более чем когда-либо существует настоятельная необходимость реабилитации этики в нашем обществе для того, чтобы вернуть человеку его достоинства. Пути насилия, эгоизм, гордость и безразличия для его же, являются основой потеря морали и этики. Это не достаточно, чтобы признать достоинства человеческой личности в нормативный акт, если личное поведение в обществе руководствуется ее.

Очевидно, что этика и мораль, однажды искупил, будет подруливающих устройств и драйверов на будущее надежды и перспективы для человечества, что хотя сталкивается с так много технологий и развития, превратил мелкой практики и основной, что более далеко мужчины социальной праздничности, которые позволяют интегрировать. Это большой вызов для современного общества, это роль этики в пороге третьего тысячелетия.

\section{ЗНАЧИМОСТЬ ПРАВА ДЛЯ СОВРЕМЕННОГО ЧЕЛОВЕКА}

Актуальность, что право играет в современном обществе структурный кризис рассмотрены fulcralmente, распространение и выражает что descortinamos в 
нашей стране, который заканчивается генерации строки самых неблагоприятных реакций угрожающие масштабы. Отсутствия моральных и этических ценностей там начать правителями, которые, вместо того чтобы давать пример гладкость и честности, предпочитают пойти противоположный путь, якорь под прикрытием безнаказанности, что восстание гражданин, который платит налоги и бороться, чтобы вести достойную жизнь и исправить. Другой сдвиг, некоторые граждане потрясен этой ситуации решимости действовать таким же образом, под обоснование что если ошибка происходит от там в нет оснований не действовать таким же образом.

Этот анархической Панорама и хаос что граждане сталкиваются в их день в день и не устали просить до когда будет продолжать наблюдать все это бессильны, без перспективы изменения, участвующих в правовой системе, которая, с ее комплекс стерильных, законы не удается создать такой гражданин защитных механизмов, которые ведет государственную структуру с ее большие налоги никаких конкретных возвращения. Очевидно то, что возможность или проспект о любых изменениях в этом состоянии вещи должны пройти серьезное и неотложное рассмотрение правовых институтов и их применение в обществе, которое оставил желать лучшего в юрисдикционные положения.

Есть много материалов, написанных на эту тему, и со временем тенденция что больше юристов и ученых права обратно, ваши глаза на эту проблему, в смысле изменения направления направлений, которые приняло право, не только в нашем обществе, но, почему бы не сказать, в мире в целом, а именно неспособность соблюдать интересы гражданина, который ищет справедливости , в ущерб этой безудержной коррупции, которая бурлит и позора судебной власти, именно по причине простого личные интересы.

Для Lênio юрист Streck (2009) право не может заполнить этот пробел в нашей правовой системе, которая увековечивает политику безнаказанности и неготовность судебной власти не для того, чтобы удовлетворить чаяния граждан, не из-за отсутствия предвидения в правовой системе, если не из-за того, что он называет «кризис». То, что юрист Гаучо предлагает парадигмы от 
текущей правовой модели развертывается в нашем обществе, которое очень далеко от текущей реальности в нашей стране.

Это именно этот «кризис» определяется Риу-Гранди-вода делителя юрист, который будет проводить поведение адвокатов в этой сложной и глобализованном обществе. Старый преступлений так противно, мораль примитивных Caveman вернуться теперь совершаться с еще большей жестокостью. Добавьте к этому другие преступления нашего поколения, как электронные преступления, как клонирование кредитных карт, остатки на банковских счетах преступных движение через электронных весов, отправка электронной почты mendaz с ссылками, которые стремятся захватить пароли в преступных целях, среди других, которые только человеческий разум способен ткать и запустить.

Ну это в этом контексте хаотичной и суматоху, что мы нашли значимость права для современного человека, потому что право, в их стремлении к справедливости, является центром рассмотрения всех этих бед, которые современный человек. С личной драмы семейного права с его холодной здравоохранения, до абсолютная неподвижность ничего, что мы можем сделать перед лицом убийства невинных людей от рук сбитый «Каратель» невменяемым и жаждой мести право должно быть пересмотрено серьезно размышлять социальные проблемы, которые возникают современный человек в полное недоумение и беспомощности перед лицом фракты что присутствие в обществе каждый день.

Значимость права, если посмотреть на моральную общества инволюции с проведения государственных руководителей, которые будут Excel в принятии закона инструмент его, против интересов регулируется неловко и неумелые в решении этой проблемы. Право должны resound личные и идеологические интересы, и если вы бросаете в поиск для данного сценария изменения что теперь представляет себя. 
Империя грубой силы был, что преобладала в нашем обществе. В дело с нарушение прав блюда весы правосудия никогда не колебаться для гражданина перед государством, гораздо меньше в пользу бедных слоев населения, сталкиваются с более богатым, или даже до привилегированных против анонимного.

Просто чтобы быть бледно понятие того, что говорят, правила гражданского процессуального установить привилегии пользу государственным органом, с quad защищать себя и Double, и мы забыли упомянуть, что государство само судья, в лице судьи, могут обжаловать его решение каждый раз, когда она выдается против государства.

И что еще хуже, предлагаемые рефрормы судебной системы в нашем обществе никогда не пользу гражданина судебном процессе; напротив все реформы в Бразилии превратил против подсудимого, в тщетной попытке убедить общество, что правосудие является медленным и что задержка в предоставлении судебного рассмотрения не только из самой судебной власти.

Это восходит к текущий момент мы живем в, который является ненасытной поисках реабилитации этики и морали в мире, таким образом, что минимальный стандарт поведения в актах о жизни в обществе и, в случае справедливости, во всем, что касается прав гражданина. Адвокаты, судьи, прокуроры, все вместе должны быть строителями новой правовой реальности, в постоянном поиске этических и моральных ценностей, достижения справедливости.

Альтернативный конфрликта решения институтах как уже упоминалось, посредничество, примирение и арбитраж, Добро пожаловать в этом восстановление процесса и поиска справедливости, поскольку он не претендует на замену судебной власти, но приходит как подтверждающие литой этот поиск для что-то новое и что, в самом деле, заполните идеалы справедливости, забыты и оставлены в стороне на протяжении всей истории. 


\section{ЗАКЛЮЧЕНИЕ}

Прежде всего, что было сказано право необходимо отказаться от этой догматической и закрытые себя на данный момент и должны идти в направлении более множественном числе. В этом глобализованном мире все нити указывали нет больше места для жесткой, однозначной видение и чрезвычайно фрормальных, напротив, можно говорить сейчас в многочисленных социальных субъектов (юристов, судей, психологов, специалистов) и плюрализм правовых институтов, которая наилучшим образом удовлетворяет интересы современного общества, включая арбитраж, посредничество и примирение.

На текущий момент приводит к замене индивидуализации роль судьи в процессе совместной ответственности других субъектов, участвующих в процессе коллективных социальных изменений (актеры вне судебной системы, как профи retromencionados), все едины в поисках твердых, ощутимые и конкретные решения для удовлетворения потребностей нынешних человек. Судебной власти должны поощрять и облегчать производства опыта, способствующих связь между себя и общества вместо дизъюнкции, фрагментации и удаленность гражданина ваша жажда справедливости.

В этой записке самой судебной власти следует поощрять налаживание партнерских связей и согласования юридической практики с институтами уже говорил что если вы знаете, опыт, смогла дать более надлежащее и удовлетворительное возвращения гражданина. Следует не существует здесь боится конкуренции, гораздо меньше страх кажась противоречия, которые могут появляться в разгар этого процесса перемен. Противоречия должны работал и не удаляются, поскольку даже несмотря на то, что некоторые из них могут показаться априори, непреодолимыми, но они не должны оставаться парализованной или утечки и истории науки состоит из строительства и деконструкции парадигмы и преодоление парадоксов.

Таким образом для каких-либо изменений, есть необходимость судебной власти открыть производство опыта, способствующих многообразие знаний и правовой 
практики, поощряя партнерство, даже различные взгляды и теории тока «статус кво». Там должен быть поиск для диалога с общественных движений и других субъектов, которые разрушить традиционные формы и burocratizadas участия граждан в их собственной истории.

Сегодня, более чем когда-либо, существует настоятельная необходимость понять, что политико-роль играет проблемы, которые представляют себя сегодня современному человеку (или постмодернистской) и понимаю, что все производство работы, направленные на структурные изменения имеет социальные последствия, или лучше сказать, что вся продукция поступает из определенных изменений и несколько властных отношений и силовые поля.

Прогулка в процесс изменения, открытые в критическом смысле и преобразовательный потенциал, зависит от работы критической самооценки судебных органов о значении и последствиях их пути действовать. Существует необходимость юридической практики основаны на взаимодействии с социальными потребностями, с проблемами глобализации, всегда делает контрапункт с текущей ситуацией судебной системы, которая будет пересмотрена и без минимальных условий для удовлетворения чаяний граждан, сталкиваются чрезмерные требования на месте там.

По этой причине судебной системы должен признать и узаконить других актеров, которые готовы внести свой вклад в решение споров и удовлетворенности граждан. Вместо того, чтобы вопрос о коллизии юрисдикций, что судебная система должна действовать сидеть в таблице с другими профессионалами в гармонии с жизненно важных потребностей человека, помимо проблем, выделил и различия, отмеченные. Что бы гигантский шаг на пути к изменению этики политика, индуктор и водитель отражения, направленных на не только самокритики, но также реальные изменения, стремится поставить права на свой истинный путь, который является стремление к справедливости в глобализованном мире, не забывая этики и морали и пилястры подлинной руководящих демократического общества, основанного на верховенстве права. 


\section{БИБЛИОГРАФИЧЕСКИЕ ССЫЛКИ}

АДЕОДЭТУС, Маурисио Јоа̃о. Этика \& риторики. 5-е издание. Сан-Паулу: Сарайва, 2012.

, Маурисио Јоа̃о. Узаконивание юридически организованной процедурой: заметки о теории Niklas Luhmann. B: Этика и риторика: на пути к теории юридической догматики. п. 53-80, Сан-Паулу: Сарайва, 2002.

Барони, Робисона. Грунтовка и профессиональной этики адвоката. 3-е изд. LTR Editora Ltda:

БОББИО, Норберто. Правовой позитивизм: уроки юриспруденции. Перевод Марсио Pugliesi, Эдсон Бини, Carlos э. Родригес, Сан-Паулу: значок, 1995.

. Общая теория политики. Даниэла перевод Beccaccia Versiani, Рио-деЖанейро: Кампус, 3. Перепечатка, 2000.

. Теория юридической системы. 10. Эд. Перевод Мария Селеста ягненка молока дос Сантос, Бразилиа: Эд. Университет Бразилиа, 1997.

Франческо КАРНЕЛУТТИ. То, что родила справа. Ricardo Родригес перевод диапазон. 1-е изд. Кампинас: Editora Рассел, 2004.

Дворкин, Рональд. Империя права. Martins Fontes: в Сан-Паулу, 2007. 4 П.

Фариа, José Eduardo, право и экономическая глобализация - последствия и перспективы, Сан-Паулу: Малейрош, 2010, 1-е издание, 3-й розыгрыш.

Фернандес-младший, введение в изучение права: техника, решение, господства. 3. Эд. Сан-Паулу: Атлас, 2001.

СЫH, Уиллис Santiago войны. Теория юридической науки. 2-е изд. Sami: в СанПаулу, 2009. 
ХАБЕРМАС, Jürgen. Права и демократии: между фрактичности и действительность. 4. ED. vol. 1. Перевод Флавий Бено Sienbeneichler, Рио-деЖанейро: бразильский время, 1997. 3 v.

Рудольф фрон JHERING. Борьба за право. Мартин Claret: в Сан-Паулу, 2003.

KELSEN, Ганс. Проблема справедливости. 2. Эд. Перевод Јоа̃о Баптиста Мачадо, Сан-Паулу: Martins Fontes, 1996.

. Что такое справедливость-справедливости, права и политики в зеркале науки. 3-е изд. Сан-Паулу: Martins Fontes, 2001.

. Общая теория права и государства. 3. Эд. Перевод Carlos Луис Borges, Сан-Паулу: Martins Fontes, 1998.

. ЧИСТАЯ ТЕОРИЯ ПРАВА. Перевести Јоа̃о Баптиста Мачадо. 6 Эд. СанПаулу: Martins Fontes, 1999, страница 1.

НАЛИНИ, José Renato. Общая и профессиональная этика. Rvista суды: СанПаулу, 1997.

Нунис, Pedro. Словарь правовых технологий. 13 Эд. Обновить: Рио-де-Жанейро, 1998.

Chaïm Перельмана. Этика и закон. Martins Fontes: в Сан-Паулу, 1996.

Реале, Miguel. Новая этика судьи. Коорд. Renato Налини José. Журнал судов: Сан-Паулу, 1994.

Спиноза, Барух. Этика. Традиц. Ксавье Lívio. Эд. Tecnoprint c.a. Ediouro: СанПаулу.

Валле, Gabriel. Étiva и право. 1-е изд. Синтез Издатель: в Сан-Паулу, 1999.

Сетхи, Vincent Paul. Нормы профессиональной этики. Юридические издатель Ltda: крепость, 1989. 
, СКАЧКОВ Eugenio Raul ЗАФФАРОНИ стиля. Судебная система, кризис, успехи

и недоразумения. Традиц. От Juarez Таварес. Эд. Журнал судов: Сан-Паулу, 1995. 